\title{
GREEN FERTILIZATION WITH RESIDUES OF LEGUMINOUS TREES FOR CULTIVATING MAIZE IN DEGRADED SOIL ${ }^{1}$
}

\author{
FRANCISCO RONALDO ALVES DE OLIVEIRA ${ }^{2 *}$, HENRIQUE ANTUNES DE SOUZA $^{3}$, MARCO ANTÔNIO ROSA \\ DE CARVALHO ${ }^{4}$, MIRIAN CRISTINA GOMES COSTA $^{5}$
}

\begin{abstract}
The objective of this study was to evaluate the effects of the addition of parts of leguminous trees on the growth and nutrition of maize (Zea mays L.), as well as on the chemical attributes of a degraded soil, 65 days after applying the residues. The experiment was conducted in pots, in a randomized block design with ten treatments and four replicates. The evaluated treatments were: T1 - No residues of leguminous trees, T2 - Leaves of Mimosa caesalpiniifolia, T3 - Branches of Mimosa caesalpiniifolia, T4 - Leaves + branches of Mimosa caesalpiniifolia, T5 - Leaves of Mimosa hostilis, T6 - Branches of Mimosa hostilis, T7 - Leaves + branches of Mimosa hostilis, T8 - Leaves of Gliricidia sepium, T9 - Branches of Gliricidia sepium and T10 Leaves + branches of Gliricidia sepium. Pots were filled with soil from a degraded area and residues were added in the form of green mass after sowing the maize. Residues of leguminous trees positively influenced maize growth at 65 days after application and favored the accumulation of nitrogen, phosphorus and potassium in the shoots. Green fertilizers improved soil chemical attributes at 65 days after application, especially nitrate$\mathrm{N}\left(\mathrm{NO}_{3}{ }^{-}-\mathrm{N}\right)$, ammonium-N $\left(\mathrm{NH}_{4}{ }^{+}-\mathrm{N}\right)$, total inorganic $\mathrm{N}\left(\mathrm{NO}_{3}{ }^{-} \mathrm{N}+\mathrm{NH}_{4}{ }^{+}-\mathrm{N}\right)$ and $\mathrm{K}$, demonstrating that these species are good options for recovering degraded areas in the semi-arid region of Ceará.
\end{abstract}

Keywords: Zea mays L.. Organic matter. Soil management. Conservation practices.

\section{ADUBAÇÃO VERDE COM RESÍDUOS DE LEGUMINOSAS ARBÓREAS PARA CULTIVO DO MILHO EM SOLO DEGRADADO}

\begin{abstract}
RESUMO - Este estudo teve como objetivo avaliar o efeito da adição de resíduos de partes de leguminosas arbóreas no crescimento e nutrição de plantas de milho (Zea mays L.), bem como nos atributos químicos de um solo degradado, 65 dias após a aplicação dos resíduos. O experimento foi realizado em vasos, em delineamento de blocos ao acaso, com dez tratamentos e quatro repetições. Os tratamentos avaliados foram: T1 - Sem resíduo de leguminosas, T2 - Folhas de Mimosa caesalpiniifolia, T3 - Galhos de Mimosa caesalpiniifolia, T4 - Folhas + galhos de Mimosa caesalpiniifolia, T5 - Folhas de Mimosa hostilis, T6 - Galhos de Mimosa hostilis, T7 Folhas + galhos de Mimosa hostilis, T8 - Folhas de Gliricidia sepium, T9 - Galhos de Gliricidia sepium e T10 Folhas + galhos de Gliricidia sepium. Os vasos foram preenchidos com solo de área degradada e os resíduos adicionados na forma de massa verde após a semeadura do milho. Resíduos de leguminosas arbóreas influenciaram positivamente o crescimento de plantas de milho já aos 65 dias após a aplicação e favoreceram o acúmulo de nitrogênio, fósforo e potássio na parte aérea de plantas. Os adubos verdes utilizados melhoraram atributos químicos do solo logo aos 65 dias após a aplicação, com destaque para o $\mathrm{N}$-nitrato $\left(\mathrm{N}^{-} \mathrm{NO}_{3}{ }^{-}\right), \mathrm{N}-$ amônio $\left(\mathrm{N}_{-} \mathrm{NH}_{4}{ }^{+}\right)$, nitrogênio inorgânico total $\left(\mathrm{N}_{-} \mathrm{NO}_{3}{ }^{-}+\mathrm{N}-\mathrm{NH}_{4}{ }^{+}\right)$e $\mathrm{K}$, demonstrando que essas espécies são boas opções para recuperação de áreas degradadas no semiárido cearense.
\end{abstract}

Palavras-chave: Zea mays L.. Matéria orgânica. Manejo do solo. Práticas de conservação.

\footnotetext{
*Corresponding author

${ }^{1}$ Received for publication in $02 / 02 / 2017$; accepted in $01 / 22 / 2018$.

Paper extracted from the master dissertation of the first author.

${ }^{2}$ Instituto Federal de Educação, Ciência e Tecnologia do Piauí, Cocal, PI, Brazil; ronaldo.oliveira@ifpi.edu.br - ORCID: 0000-0003-47526387.

${ }^{3}$ Embrapa Meio-Norte, Teresina, PI, Brazil; henrique.souza@embrapa.br - ORCID: 0000-0002-2209-4285.

${ }^{4}$ Instituto Federal de Educação, Ciência e Tecnologia do Ceará, Sobral, CE, Brazil; marcorosa@ifce.edu.br - ORCID: 0000-0001-89224673 .

${ }^{5}$ Department of Soil Science, Universidade Federal do Ceará, Fortaleza, CE, Brazil; mirian.costa@ufc.br - ORCID: 0000-0002-4682-4756.
} 


\section{INTRODUCTION}

In northeastern Brazil, deforestation associated with opening new areas for agricultural exploitation, firewood and charcoal production, and the lack of soil conservation practices have contributed to soil degradation. Soils of this region often have low fertility, which limits agricultural production (MUNDUS et al., 2008). Among family farms in the Sertão Inhamuns region, Ceará state, 90 and $50 \%$ of studied areas showed low organic matter (OM) and phosphorus (P) contents (SOUZA et al., 2015). Green fertilization with leguminous plants can be an option for agricultural systems in the Ceará state, because of the capacity of these species to add $\mathrm{OM}$ and significant quantities of nutrients, especially nitrogen $(\mathrm{N})$. This can improve the chemical, physical and biological properties of soil, which in turn improves crop development (ANDRADE NETO et al., 2010; PRIMO et al., 2012; PEREIRA; SOARES; MIRANDA, 2016). In some cases, the amount of $\mathrm{N}$ supplied by these species can exceed $200 \mathrm{~kg} \mathrm{ha}^{-1}$ (DINIZ et al., 2010).

The decomposition of the leguminous plants may occur in a relatively short time because of the low C:N relationship. Species such as Crotalaria spectabilis studied in cultivation in the Ceará presented half-life times $\left(\mathrm{t}_{1 / 2}\right)$ of 65,53 and 54 days for N, P and K (PEREIRA; SOARES; MIRANDA, 2016).

There are many methods of using leguminous species to improve soil fertility and agricultural crops. In semi-arid regions, agroforestry systems with alley cultivation (alley cropping), which are the intercropping of leguminous shrub/tree species with the food crop of interest, can be one method, since periodic tree pruning results in green fertilization (PAULINO et al., 2011).

Implementing alleys as a form of land use in tropical regions is an option for managing degraded areas, especially sites where small farms prevail (SAMPAIO et al., 2015). There is still lack of information however on the nutrition of agricultural crops through green fertilization using leguminous trees in semi-arid regions, as well as on the best species to use and which parts of the plant best promote improvements in soil fertility.

This study was based on the hypotheses that one of the leguminous species evaluated will promote better development, greater accumulation and more efficiently recover macronutrients from the maize crop; residues from leguminous trees can improve soil chemical attributes at 65 days after application; and improvements in soil chemical attributes depend on the added plant part.

Given the above, this study aimed to evaluate the effect of adding residues from different parts of leguminous trees on the growth and nutrition of maize, as well as on the alterations of soil chemical attributes 65 days after applying the residues.

\section{MATERIAL AND METHODS}

The experiment was carried out from August to October 2012 in the facilities of a seedlings nursery located in Sobral municipality, Ceará State, Brazil, located at $3^{\circ} 41^{\prime} \mathrm{S}$ and $40^{\circ} 20^{\prime} \mathrm{W}$, altitude of $69 \mathrm{~m}$. The climate is BShw (hot semiarid) according to the Köppen classification system, with the rainy season lasting from January to June. The average annual temperature is $28{ }^{\circ} \mathrm{C}$ and average historical rainfall is $759 \mathrm{~mm} \mathrm{yr}^{-1}$ (SOUZA et al., 2016).

The experimental design was conducted in randomized blocks, with ten treatments and four replicates. Each experimental plot consisted of one pot with $10 \mathrm{dm}^{3}$ capacity, containing one plant. The soil received residues from three leguminous species, 'sabiá' (Mimosa caesalpiniifolia Benth), 'juremapreta' (Mimosa hostilis) and 'gliricídia' (Gliricidia sepium), with the following treatments: T1 - No residues of leguminous species, T2 - Leaves of $M$. caesalpiniifolia, T3 - Branches of $M$. caesalpiniifolia, T4 - Leaves + branches of $M$. caesalpiniifolia, T5 - Leaves of M. hostilis, T6 Branches of $M$. hostilis, T7 - Leaves + branches of M. hostilis, T8 - Leaves of G. sepium, T9 - Branches of G. sepium and T10 - Leaves + branches of $G$. sepium.

Pots were filled with Luvisol (EMBRAPA, 2006), collected from the $0.0-0.3 \mathrm{~m}$ soil layer in a visibly degraded area, absent vegetation and in the presence of laminar erosion, in the district of Jaibaras, Sobral-CE municipality $\left(3^{\circ} 43^{\prime} 30^{\prime \prime} \mathrm{S}, 40^{\circ}\right.$ 22,30 " W) in a region in the desertification nucleus of Irauçuba (CE).

After being transported to the experimental area (seedling nursery), the soil was sieved through a 4.0-mm mesh to retain the coarser material. A composite sample was also collected and air-dried and sieved through a $2.0-\mathrm{mm}$ mesh, for physical and chemical characterization (DONAGEMA et al., 2011), with the following results: $\mathrm{pH}=5.7$; $\mathrm{EC}=$ $0.50 \mathrm{dS} \mathrm{m}^{-1} ;$ TOC $=5.1\left(\mathrm{~g} \mathrm{~kg}^{-1}\right) ; \mathrm{P}=3.9\left(\mathrm{mg} \mathrm{dm}^{-3}\right)$; $\mathrm{K}=2.6 ; \mathrm{Na}=4.2 ; \mathrm{Ca}=14.6 ; \mathrm{Mg}=5.8 ; \mathrm{Al}=2.0 ; \mathrm{H}$ $+\mathrm{Al}=13.8 \mathrm{mmol}_{\mathrm{c}} \mathrm{dm}^{-3}$; Sand $=731$; Silt $=192$; Clay $=77\left(\mathrm{~g} \mathrm{~kg}^{-1}\right)$; textural class $=$ sandy loam.

Samples of the plant residues that comprised the treatments were collected for chemical characterization by determining the contents of $\mathrm{C}, \mathrm{N}$, $\mathrm{P}, \mathrm{K}, \mathrm{Ca}$ and $\mathrm{Mg}$ (SILVA, 2009), whose results are presented in Table 1.

Each pot received $8.0 \mathrm{dm}^{3}$ of soil, measured with a 1.0 -L cylinder. Based on the results of the chemical characterization analysis, the soil received $108.8 \mathrm{mg} \mathrm{dm}^{-3}$ of triple superphosphate, which corresponded to $90 \mathrm{~kg} \mathrm{ha}^{-1}$ of $\mathrm{P}_{2} \mathrm{O}_{5}$ (FERNANDES, 1993), using triple superphosphate as source. 
F. R. A. OLIVEIRA et al.

Table 1. Chemical characterization of leguminous plant residues used in the study.

\begin{tabular}{ccccccccc}
\hline \multirow{2}{*}{ Species } & $\begin{array}{c}\text { Part of } \\
\text { the plant }\end{array}$ & $\mathrm{C}$ & $\mathrm{N}$ & $\mathrm{P}$ & $\mathrm{K}$ & $\mathrm{Ca}$ & $\mathrm{Mg}$ & $\mathrm{C} / \mathrm{N}$ \\
& Leaf & 434.8 & 14.1 & 0.8 & 9.0 & 7.0 & 2.5 & 30.8 \\
\hline \multirow{2}{*}{ M. caesalpiniifolia } & Branch* & 506.1 & 6.7 & 0.8 & 6.8 & 6.3 & 0.9 & 75.5 \\
& Leaf & 449.8 & 17.2 & 0.9 & 7.4 & 6.9 & 2.8 & 26.2 \\
\multirow{2}{*}{ M. hostilis } & Branch & 517.3 & 8.6 & 1.0 & 6.0 & 4.5 & 0.6 & 60.2 \\
& Leaf & 427.3 & 22.2 & 1.4 & 14.7 & 8.1 & 4.3 & 19.2 \\
\multirow{2}{*}{ G. sepium } & Branch & 461.1 & 11.6 & 1.7 & 12.7 & 6.3 & 2.2 & 39.8 \\
\hline
\end{tabular}

*Branches with diameter $\leq 1.0 \mathrm{~cm}$.

After sowing the maize (Zea mays L.) variety 'BRS Gorutuba', the leguminous species residues were applied in pots in the form of green mass. The amount applied in each pot was equivalent to $73.0 \mathrm{~g}$ of dry matter, corresponding to $17,300 \mathrm{~kg} \mathrm{ha}^{-1}$, considering the mean dry biomass production (leaves + thin branches) of the three studied species in $\mathrm{kg}$ plant year ${ }^{-1}$ (BAKKE et al., 2007; FERREIRA et al., 2007; MARIN et al., 2006). The equivalence for dry matter was obtained through the water contents in the leaves and branches of each species. In the treatments composed of leaves + branches, the proportion was $50 \%$ for each plant part. To obtain the fraction "branches", branches with diameter $\leq 1.0 \mathrm{~cm}$ were selected and cut into pieces approximately $2.0 \mathrm{~cm}$ in length. The quantities of $\mathrm{N}$, $\mathrm{P}, \mathrm{K}, \mathrm{Ca}$ and $\mathrm{Mg}$ contained in the residues applied in the pots are shown (Table 2).

Table 2. Amounts of nitrogen $(\mathrm{N})$, phosphorus $(\mathrm{P})$, potassium $(\mathrm{K})$, calcium $(\mathrm{Ca})$ and magnesium $(\mathrm{Mg})$ from the residues of leguminous trees added to the soil.

\begin{tabular}{|c|c|c|c|c|c|}
\hline \multirow{2}{*}{ Treatments } & $\mathrm{N}$ & $\mathrm{P}$ & $\mathrm{K}$ & $\mathrm{Ca}$ & $\mathrm{Mg}$ \\
\hline & \multicolumn{5}{|c|}{ - } \\
\hline M. caesalpiniifolia $(\mathrm{L})$ & 1029.3 & 60.5 & 657.0 & 511.7 & 182.5 \\
\hline M. caesalpiniifolia (B) & 489.1 & 61.3 & 496.4 & 460.6 & 65.7 \\
\hline M. caesalpiniifolia $(\mathrm{L}+\mathrm{B})$ & 759.2 & 60.9 & 576.7 & 486.1 & 124.1 \\
\hline M. hostilis (L) & 1255.6 & 62.0 & 540.2 & 503.7 & 204.4 \\
\hline M. hostilis (B) & 627.8 & 75.1 & 438.0 & 330.6 & 43.8 \\
\hline M. hostilis $(\mathrm{L}+\mathrm{B})$ & 941.7 & 68.6 & 489.1 & 417.1 & 124.1 \\
\hline G. sepium $(\mathrm{L})$ & 1620.6 & 103.6 & 1073.1 & 593.4 & 313.9 \\
\hline G. sepium (B) & 846.8 & 125.5 & 927.1 & 462.0 & 160.6 \\
\hline G. sepium $(\mathrm{L}+\mathrm{B})$ & 1233.7 & 114.6 & 1000.1 & 527.7 & 237.2 \\
\hline
\end{tabular}

Pots were irrigated daily using water from the municipal supply system of Sobral-CE, analysis showed the following chemical characteristics: $\mathrm{pH}=7.0 ; \quad \mathrm{EC}=0.22 \mathrm{dS} \mathrm{m} \mathrm{m}^{-1}$; $\mathrm{Ca}=0.50 ; \mathrm{Mg}=0.75 ; \quad \mathrm{K}=0.20 ; \mathrm{Na}=0.70$; $\mathrm{Cl}^{-}=1.25 ; \mathrm{HCO}_{3}{ }^{-}=1.0\left(\mathrm{mmol}_{\mathrm{c}} \mathrm{L}^{-1}\right)$. Initially, a water volume was applied to increase soil moisture to $80 \%$ of field capacity. Starting on the second day, the water depth to be applied was determined by weighing each pot and calculating the difference in mass relative to the previous day.

The seedlings were thinned 15 days after sowing (DAS), leaving the most vigorous plant in each pot. The plants were collected at 65 DAS, when $80 \%$ had already produced female inflorescence. Maize growth was evaluated by determining plant height $(\mathrm{PH})$, number of leaves (NL), stem diameter
(SD), root dry matter (RDM), shoot dry matter (SDM) and total dry matter (TDM).

$\mathrm{PH}, \mathrm{SD}$ and NL were determined in the experimental area. To obtain SDM (stem, leaves and inflorescences) and RDM, plants were cut close to the soil, separated into roots and shoots and dried in an oven with air circulation and renewal at $60-65^{\circ} \mathrm{C}$. TDM was obtained by adding RDM and SDM.

SDM samples were ground in a Wiley-type mill and used to determine the contents of N, P, K, $\mathrm{Ca}$ and $\mathrm{Mg}$, following Silva (2009). Nutrient accumulation in maize plants was calculated by multiplying shoot dry matter by the contents of each nutrient.

Soil sampling was performed after plant collection in the $0.0-0.1 \mathrm{~m}$ layer, by collecting one sample for analyzing $\mathrm{pH}, \mathrm{EC}, \mathrm{TOC}, \mathrm{P}, \mathrm{Na}, \mathrm{K}, \mathrm{Ca}$, 
$\mathrm{Mg}, \mathrm{Al}$ and $(\mathrm{H}+\mathrm{Al})$, and another for analyzing nitrate- $\mathrm{N}\left(\mathrm{NO}_{3}{ }^{-}-\mathrm{N}\right)$ and ammonium-N $\left(\mathrm{NH}_{4}{ }^{+}-\mathrm{N}\right)$, determined through steam distillation (DONAGEMA et al., 2011). Total inorganic $\mathrm{N}\left(\mathrm{NO}_{3}^{-}-\mathrm{N}+\mathrm{NH}_{4}^{+}-\mathrm{N}\right)$ was obtained by the sum of the contents of $\mathrm{NO}_{3}{ }^{-} \mathrm{N}$ and $\mathrm{NH}_{4}{ }^{+}-\mathrm{N}$. Recovery efficiency (RE) is the amount of nutrient accumulated per unit of nutrient applied, usually expressed in percentage, calculated by Equation 1:

$$
\mathrm{RE}=\left[\frac{\mathrm{NAWF}-\mathrm{NAWoF}}{\mathrm{AAN}}\right] \times 100
$$

Where RE is the recovery efficiency (\%), NAWF is nutrient accumulation with fertilization $(\mathrm{kg})$, NAWoF is nutrient accumulation without fertilization $(\mathrm{kg})$ and $\mathrm{AAN}$ is the amount of nutrient applied $(\mathrm{kg})$.

The obtained data were subjected to the Kolmogorov-Smirnov test to verify normality and the $\mathrm{F}$ test for analysis of variance. When significant, means were compared by the Tukey test. All tests were done at a 0.05 probability level, using the statistical software SISVAR (FERREIRA, 2011).

\section{RESULTS AND DISCUSSION}

Results obtained for PH (Table 3) showed the addition of leaves + branches of $G$. sepium led to higher values compared to the other residues, except for the leaves of $M$. hostilis and leaves + branches of M. caesalpiniifolia. This can be explained by the fact that the "leaves" fraction has a low C:N ratio, especially leaves of $G$. sepium (Table 1), favoring faster decomposition and later supply of $\mathrm{N}$ to the crop. In addition, the mixture with branches may have favored a greater synchronism in the release of nutrients, since they have lower $\mathrm{C}: \mathrm{N}$ ratio and thus undergo slower decomposition. These results corroborate Andrade Neto et al. (2010), who studied the effects of green fertilization on forage sorghum growth and yield and also observed a positive influence on plant height.

Table 3. Mean values of plant height (PH), number of leaves per plant (NL), stem diameter (SD), root dry matter (RDM), shoot dry matter (SDM) and total dry matter (TDM) of maize plants at 65 DAS.

\begin{tabular}{|c|c|c|c|c|c|c|}
\hline \multirow{2}{*}{ Treatments } & PH & NL & $\mathrm{SD}$ & RDM & SDM & TDM \\
\hline & $(\mathrm{cm})$ & & $(\mathrm{mm})$ & \multicolumn{3}{|c|}{ - $\left(\mathrm{g} \mathrm{plant}^{-1}\right)$} \\
\hline Without residue & $112.0 \mathrm{bc}$ & $7.7 \mathrm{a}$ & $5.5 \mathrm{a}$ & $0.3 \mathrm{~b}$ & $8.2 \mathrm{c}$ & $8.5 \mathrm{c}$ \\
\hline M. caesalpiniifolia $(\mathrm{L})$ & $113.7 \mathrm{bc}$ & $8.2 \mathrm{a}$ & $6.6 \mathrm{a}$ & $0.4 \mathrm{ab}$ & $11.2 \mathrm{ab}$ & $11.6 \mathrm{ab}$ \\
\hline M. caesalpiniifolia $(\mathrm{B})$ & $108.5 \mathrm{~cd}$ & $8.7 \mathrm{a}$ & $5.2 \mathrm{a}$ & $0.4 \mathrm{ab}$ & $10.5 \mathrm{~b}$ & $10.9 \mathrm{ab}$ \\
\hline M. caesalpiniifolia $(\mathrm{L}+\mathrm{B})$ & $117.0 \mathrm{abc}$ & $8.2 \mathrm{a}$ & $5.8 \mathrm{a}$ & $0.5 \mathrm{a}$ & $11.2 \mathrm{ab}$ & $11.7 \mathrm{ab}$ \\
\hline M. hostilis (L) & $121.5 \mathrm{ab}$ & $8.5 \mathrm{a}$ & $5.9 \mathrm{a}$ & $0.4 \mathrm{ab}$ & $11.5 \mathrm{ab}$ & $11.9 \mathrm{ab}$ \\
\hline M. hostilis (B) & $100.0 \mathrm{~d}$ & $9.2 \mathrm{a}$ & $6.0 \mathrm{a}$ & $0.4 \mathrm{ab}$ & $11.0 \mathrm{ab}$ & $11.4 \mathrm{ab}$ \\
\hline M. hostilis $(\mathrm{L}+\mathrm{B})$ & $110.5 \mathrm{~cd}$ & $7.2 \mathrm{a}$ & $5.1 \mathrm{a}$ & $0.4 \mathrm{ab}$ & $11.5 \mathrm{ab}$ & $11.9 \mathrm{ab}$ \\
\hline G. sepium $(\mathrm{L})$ & $113.0 \mathrm{bc}$ & $7.5 \mathrm{a}$ & $6.2 \mathrm{a}$ & $0.4 \mathrm{ab}$ & $12.0 \mathrm{ab}$ & $12.4 \mathrm{ab}$ \\
\hline G. sepium $(\mathrm{B})$ & $110.0 \mathrm{~cd}$ & $8.0 \mathrm{a}$ & $5.9 \mathrm{a}$ & $0.4 \mathrm{ab}$ & $11.0 \mathrm{ab}$ & $11.4 \mathrm{ab}$ \\
\hline G. sepium $(\mathrm{L}+\mathrm{B})$ & $127.2 \mathrm{a}$ & $9.7 \mathrm{a}$ & $6.4 \mathrm{a}$ & $0.4 \mathrm{ab}$ & $12.5 \mathrm{a}$ & $12.9 \mathrm{a}$ \\
\hline F values & $11.6^{* *}$ & $1.8^{\mathrm{ns}}$ & $0.93^{\mathrm{ns}}$ & $2.2 *$ & $8.1 * *$ & $8.8^{* *}$ \\
\hline CV $(\%)$ & 3.8 & 14.2 & 12.2 & 11.9 & 7.2 & 7.4 \\
\hline
\end{tabular}

Means followed by the same letter in the column did not differ by the Tukey test at $\mathrm{p}<0.05$; **Significant at $\mathrm{p}<$ 0.01 ; *Significant at $\mathrm{p}<0.05 ;{ }^{\mathrm{ns}}$ Not significant at $\mathrm{p}<0.05 ;(\mathrm{L})=$ Leaves, $(\mathrm{B})=$ Branches and $(\mathrm{L}+\mathrm{B})=$ Leaves + Branches; $\mathrm{CV}=$ Coefficient of variation.

RDM was influenced by the application of leaves + branches of $M$. caesalpiniifolia, which differed only from the control (without residue application). All residues positively affected SDM and TDM, showing the potential of these species to promote maize development, since the dry matter is an important parameter for evaluating plant development. This effect of leguminous trees on the increase in maize biomass may result from a synchronized release of $\mathrm{N}$ in the soil, causing greater absorption by plants, since the residues were not incorporated, thus favoring a slower decomposition (SOUZA et al., 2016).

All residues applied to the soil positively influenced $\mathrm{N}$ accumulation (Table 4). This result is explained by the fact that these species have high $\mathrm{N}$ contents and release significant quantities to the soil, which favors absorption and accumulation by maize plants (DINIZ et al., 2010; PRIMO et al., 2012). Although leaves + branches of $G$. sepium had the highest absolute value, the effect of this residue differed statistically only from the addition of 
branches of M. hostilis, branches of $M$. caesalpiniifolia and the control. The application of leaves + branches of $G$. sepium led to a $61.4 \%$ increase of $\mathrm{N}$ accumulation compared to plants that did not receive any residue. In addition to presenting a lower C:N ratio (Table 1), the residue of G. sepium is a high quality material, having low contents of polyphenol and lignin (MUNDUS et al., 2008).

Table 4. Accumulation of nitrogen $(\mathrm{N})$, phosphorus $(\mathrm{P})$, potassium $(\mathrm{K})$, calcium $(\mathrm{Ca})$ and magnesium $(\mathrm{Mg})$ in the shoots of maize plants at 65 DAS.

\begin{tabular}{|c|c|c|c|c|c|}
\hline \multirow{2}{*}{ Treatments } & $\mathrm{N}$ & $\mathrm{P}$ & $\mathrm{K}$ & $\mathrm{Ca}$ & $\mathrm{Mg}$ \\
\hline & \multicolumn{5}{|c|}{---------------------------- $\left({ }^{\prime}\right.$} \\
\hline Without residue & $136.9 \mathrm{c}$ & $13.4 \mathrm{~b}$ & $113.9 \mathrm{c}$ & $44.0 \mathrm{~b}$ & $16.1 \mathrm{~b}$ \\
\hline M. caesalpiniifolia $(\mathrm{L})$ & $195.5 \mathrm{ab}$ & $19.1 \mathrm{a}$ & $191.8 \mathrm{ab}$ & $64.1 \mathrm{ab}$ & $27.1 \mathrm{ab}$ \\
\hline M. caesalpiniifolia $(\mathrm{B})$ & $181.5 \mathrm{~b}$ & $18.2 \mathrm{a}$ & $161.0 \mathrm{bc}$ & $61.3 \mathrm{ab}$ & $24.7 \mathrm{ab}$ \\
\hline M. caesalpiniifolia $(\mathrm{L}+\mathrm{B})$ & $195.6 \mathrm{ab}$ & $19.4 \mathrm{a}$ & $175.0 \mathrm{ab}$ & $68.2 \mathrm{ab}$ & $30.8 \mathrm{ab}$ \\
\hline M. hostilis (L) & $201.0 \mathrm{ab}$ & $19.7 \mathrm{a}$ & $197.6 \mathrm{ab}$ & $74.8 \mathrm{a}$ & $31.9 \mathrm{ab}$ \\
\hline M. hostilis (B) & $185.7 \mathrm{~b}$ & $18.3 \mathrm{a}$ & $169.0 \mathrm{abc}$ & $60.9 \mathrm{ab}$ & $27.4 \mathrm{ab}$ \\
\hline M. hostilis $(\mathrm{L}+\mathrm{B})$ & $195.5 \mathrm{ab}$ & $18.8 \mathrm{a}$ & $190.1 \mathrm{ab}$ & $64.5 \mathrm{ab}$ & $24.2 \mathrm{ab}$ \\
\hline G. sepium (L) & $205.0 \mathrm{ab}$ & $19.9 \mathrm{a}$ & $204.7 \mathrm{ab}$ & $68.6 \mathrm{a}$ & $40.4 \mathrm{a}$ \\
\hline G. sepium (B) & $194.7 \mathrm{ab}$ & $18.7 \mathrm{a}$ & $193.4 \mathrm{ab}$ & $64.7 \mathrm{ab}$ & $29.7 \mathrm{ab}$ \\
\hline G. sepium $(\mathrm{L}+\mathrm{B})$ & $223.0 \mathrm{a}$ & $21.8 \mathrm{a}$ & $221.3 \mathrm{a}$ & $75.5 \mathrm{a}$ & $37.8 \mathrm{a}$ \\
\hline F values & $11.5^{* *}$ & $7.7 * *$ & $6.5^{* *}$ & $3.1 *$ & $3.5^{* *}$ \\
\hline CV (\%) & 6.9 & 8.3 & 12.9 & 15.5 & 25.7 \\
\hline
\end{tabular}

Means followed by the same letter in the column did not differ by the Tukey test at $\mathrm{p}<0.05$; **Significant at $\mathrm{p}<0.01$; *Significant at $\mathrm{p}<0.05$; ${ }^{\text {ns }}$ Not significant at $\mathrm{p}<0.05 ;(\mathrm{L})=$ Leaves, $(\mathrm{B})=$ Branches and $(\mathrm{L}+\mathrm{B})=$ Leaves + Branches; $\mathrm{CV}=$ Coefficient of variation.

As for $\mathrm{P}$ accumulation, the residue applications to means that were statistically tied, but higher than the control. This indicates the residues caused $\mathrm{P}$ accumulation in the vegetative part of maize plants, regardless of species or plant part used.

Regarding $\mathrm{K}$ accumulation in the shoots of maize plants, the highest mean was obtained with the addition of G. sepium leaves + branches to the soil. This value differed statistically however only from the means caused by leaves + branches of $M$. caesalpiniifolia and the control, which had the lowest mean. Leaves + branches of G. sepium caused a $94.3 \%$ increase in $\mathrm{K}$ accumulation compared to the control. According to Ernani, Almeida and Santos (2007), $\mathrm{K}$ is washed from the organic material immediately after the death of the cells. Thus, when plant biomass is added to the soil, the response of the crops to $\mathrm{K}$ absorption can be faster in relation to the absorption of nutrients that depend on the decomposition and mineralization performed by microorganisms.

For $\mathrm{Ca}$ accumulation in the shoots of maize plants, only leaves + branches of $G$. sepium, leaves of $G$. sepium and leaves of $M$. hostilis resulted in higher means compared to the control, but did not differ statistically. For $\mathrm{Mg}$ accumulation, only maize plants that received leaves of $G$. sepium and leaves + branches of $G$. sepium were higher than the control.

Mimosa caesalpiniifolia branches promoted higher recovery efficiency ( $\mathrm{RE}$ ) of $\mathrm{N}$ in comparison to $M$. hostilis leaves and G. sepium leaves, with these being statistically equal to the other residues (Table $5)$. It is possible that the difference observed for M. caesalpiniifolia was due to this residue having the highest $\mathrm{C}: \mathrm{N}$ ratio among those studied (Table 1), which favored slower decomposition of the material and therefore better use by plants. According to Fontanétti et al. (2006), crop efficiency in N recovery is associated with the synchronism between the release of $\mathrm{N}$ from green fertilizers and its absorption by plants.

For P, leaves + branches of M. caesalpiniifolia and leaves of $M$. hostilis promoted higher RE compared to branches of G. sepium and were statistically equal to the other treatments. In most treatments, the $\mathrm{P}$ recovery percentage was higher than that of $\mathrm{N}$, which can be explained by the phosphate fertilization applied to the soil before planting.

From the observed data, it was possible to quantify the mean recovery rate of each leguminous species, as these values can contribute to fertilization management using green fertilizers in the maize crop. Thus, the following mean values are cited for each species (leaves, branches and leaves + branches), relative to $\mathrm{N}, \mathrm{P}$ and $\mathrm{K}$ : M. caesalpiniifolia (7.5, 9.1 and 10.6\%), M. hostilis (6.4, 8.26 and 14.5\%) and G. sepium (6.0, 5.9 and $9.2 \%$ ). Total organic carbon (TOC) was positively affected by the residues of the leguminous plants and leaves of $M$. hostilis and 
leaves + branches of $G$. sepium resulted in means higher than those of the control, not differing from the other treatments (Table 6). This difference, in relation to the control, can be explained by the fact that these two species have lower $\mathrm{C}: \mathrm{N}$ ratios (Table 1), favoring a higher speed in the process of decomposition of the residues.

Table 5. Mean values of recovery efficiency $(\mathrm{RE})$ of nitrogen $(\mathrm{N})$, phosphorus $(\mathrm{P})$, potassium $(\mathrm{K})$, calcium $(\mathrm{Ca})$ and magnesium $(\mathrm{Mg})$ in the maize crop cultivated with addition of residues of leguminous trees.

\begin{tabular}{|c|c|c|c|c|c|}
\hline \multirow{2}{*}{ Treatments } & $\mathrm{N}$ & $\mathrm{P}$ & $\mathrm{K}$ & $\mathrm{Ca}^{* * *}$ & $\mathrm{Mg}^{* * *}$ \\
\hline & \multicolumn{5}{|c|}{ 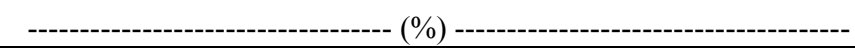 } \\
\hline M. caesalpiniifolia $(\mathrm{L})$ & $5.7 \mathrm{ab}$ & $9.5 \mathrm{ab}$ & $11.9 \mathrm{a}$ & $1.9 \mathrm{a}$ & $2.3 \mathrm{a}$ \\
\hline M. caesalpiniifolia $(\mathrm{B})$ & $9.1 \mathrm{a}$ & $8.0 \mathrm{ab}$ & $9.5 \mathrm{a}$ & $1.7 \mathrm{a}$ & $3.4 \mathrm{a}$ \\
\hline M. caesalpiniifolia $(\mathrm{L}+\mathrm{B})$ & $7.7 \mathrm{ab}$ & $9.9 \mathrm{a}$ & $10.6 \mathrm{a}$ & $2.1 \mathrm{a}$ & $3.3 \mathrm{a}$ \\
\hline M. hostilis (L) & $5.1 \mathrm{~b}$ & $10.2 \mathrm{a}$ & $12.6 \mathrm{a}$ & $2.4 \mathrm{a}$ & $2.7 \mathrm{a}$ \\
\hline M. hostilis (B) & $7.8 \mathrm{ab}$ & $6.6 \mathrm{ab}$ & $15.6 \mathrm{a}$ & $2.2 \mathrm{a}$ & $4.6 \mathrm{a}$ \\
\hline M. hostilis $(\mathrm{L}+\mathrm{B})$ & $6.2 \mathrm{ab}$ & $8.0 \mathrm{ab}$ & $8.5 \mathrm{a}$ & $2.1 \mathrm{a}$ & $2.4 \mathrm{a}$ \\
\hline G. sepium (L) & $4.2 \mathrm{~b}$ & $6.3 \mathrm{ab}$ & $8.6 \mathrm{a}$ & $1.9 \mathrm{a}$ & $2.7 \mathrm{a}$ \\
\hline G. sepium (B) & $6.8 \mathrm{ab}$ & $4.3 \mathrm{~b}$ & $8.6 \mathrm{a}$ & $2.1 \mathrm{a}$ & $2.8 \mathrm{a}$ \\
\hline G. sepium $(\mathrm{L}+\mathrm{B})$ & $7.0 \mathrm{ab}$ & $7.3 \mathrm{ab}$ & $10.7 \mathrm{a}$ & $2.4 \mathrm{a}$ & $3.0 \mathrm{a}$ \\
\hline F values & $3.4 * *$ & $2.7^{*}$ & $2.1 \mathrm{~ns}$ & $0.8^{\mathrm{ns}}$ & $1.9^{\mathrm{ns}}$ \\
\hline CV $(\%)$ & 24.6 & 29.6 & 32 & 26 & 33.2 \\
\hline
\end{tabular}

*** Data transformed to square root; Means followed by the same letter in the column did not differ by the Tukey test at $\mathrm{p}<0.05$; ${ }^{* *}$ Significant at $\mathrm{p}<0.01$; ${ }^{*}$ Significant at $\mathrm{p}<0.05$; ${ }^{\text {ns }}$ Not significant at $\mathrm{p}<0.05 ;(\mathrm{L})=$ Leaves, (B) $=$ Branches and $(\mathrm{L}+\mathrm{B})=$ Leaves + Branches; $\mathrm{CV}=$ Coefficient of variation .

The residues of the leguminous plants did not cause an increase in soil $\mathrm{pH}$ (Table 1) while the leaves / leaves + branches of $M$. hostilis caused a reduction. In this case, the organic matter added to the soil through the residues acted as source of acidity. A possible explanation is that, at 65 days after the addition, the residues were still decomposing, releasing $\mathrm{H}^{+}$and reducing the $\mathrm{pH}$. On this topic, Silva and Mendonça (2007) report that adding organic matter will increase or decrease the soil $\mathrm{pH}$, depending on the predominance of processes that consume or release $\mathrm{H}^{+}$.

Table 6. Mean values of total organic carbon (TOC), hydrogen potential $(\mathrm{pH})$, aluminum (Al), potential acidity $(\mathrm{H}+\mathrm{Al})$, aluminum saturation $(\mathrm{m})$, nitrate- $\mathrm{N}\left(\mathrm{NO}_{3}{ }^{-} \mathrm{-N}\right)$, ammonium- $\mathrm{N}\left(\mathrm{NH}_{4}{ }^{+}-\mathrm{N}\right)$ and total inorganic nitrogen $\left(\mathrm{NO}_{3}{ }^{-}-\mathrm{N}+\mathrm{NH}_{4}{ }^{+}-\mathrm{N}\right)$ in the first $10 \mathrm{~cm}$ of the soil after maize cultivation with addition of residues of leguminous trees.

\begin{tabular}{|c|c|c|c|c|c|c|c|c|}
\hline \multirow{2}{*}{ Treatments } & \multirow{2}{*}{$\frac{\mathrm{TOC}}{\mathrm{g} \mathrm{dm}^{-3}}$} & \multirow{2}{*}{$\frac{\mathrm{pH}}{-}$} & $\mathrm{Al}$ & $(\mathrm{H}+\mathrm{Al})$ & \multirow{2}{*}{$\begin{array}{l}\mathrm{m} \\
\%\end{array}$} & $\mathrm{NO}_{3}{ }^{-}-\mathrm{N}$ & $\mathrm{NH}_{4}^{+}-\mathrm{N}$ & $\begin{array}{c}\mathrm{NO}_{3}{ }^{-}-\mathrm{N}+ \\
\mathrm{NH}_{4}{ }^{+}-\mathrm{N}\end{array}$ \\
\hline & & & \multicolumn{2}{|c|}{$---\mathrm{mmol}_{\mathrm{c}} \mathrm{dm}^{-3}---$} & & \multicolumn{3}{|c|}{$--------\mathrm{mg} \mathrm{dm}^{-3}-------$} \\
\hline Without residue & $4.8 \mathrm{~b}$ & $5.7 \mathrm{a}$ & $1.0 \mathrm{a}$ & $13.8 \mathrm{ab}$ & $3.5 \mathrm{ab}$ & $9.2 \mathrm{e}$ & $4.9 \mathrm{e}$ & $14.2 \mathrm{~d}$ \\
\hline M. caesalpiniifolia $(\mathrm{L})$ & $5.2 \mathrm{ab}$ & $5.5 \mathrm{ab}$ & $1.0 \mathrm{a}$ & $14.2 \mathrm{ab}$ & $3.6 \mathrm{ab}$ & $10.1 \mathrm{de}$ & 5.2 cde & $15.3 \mathrm{~cd}$ \\
\hline M. caesalpiniifolia $(\mathrm{B})$ & $5.3 \mathrm{ab}$ & $5.8 \mathrm{a}$ & $1.0 \mathrm{a}$ & $13.7 \mathrm{~b}$ & $3.3 \mathrm{ab}$ & $11.0 \mathrm{bcd}$ & $5.0 \mathrm{de}$ & $16.0 \mathrm{bc}$ \\
\hline M. caesalpiniifolia $(\mathrm{L}+\mathrm{B})$ & $5.2 \mathrm{ab}$ & $5.5 \mathrm{ab}$ & $1.0 \mathrm{a}$ & $14.7 \mathrm{ab}$ & $3.4 \mathrm{ab}$ & $10.8 \mathrm{~cd}$ & $5.5 \mathrm{abc}$ & $16.3 \mathrm{bc}$ \\
\hline M. hostilis (L) & $6.3 \mathrm{a}$ & $5.1 \mathrm{~b}$ & $1.0 \mathrm{a}$ & $14.9 \mathrm{ab}$ & $3.9 \mathrm{a}$ & $11.1 \mathrm{bcd}$ & $5.2 \mathrm{cde}$ & $16.3 \mathrm{bc}$ \\
\hline M. hostilis (B) & $5.6 \mathrm{ab}$ & $5.7 \mathrm{a}$ & $1.0 \mathrm{a}$ & $14.7 \mathrm{ab}$ & $3.3 \mathrm{ab}$ & $10.9 \mathrm{bcd}$ & $5.3 \mathrm{cde}$ & $16.2 \mathrm{bc}$ \\
\hline M. hostilis $(\mathrm{L}+\mathrm{B})$ & $5.7 \mathrm{ab}$ & $5.2 \mathrm{~b}$ & $1.0 \mathrm{a}$ & $15.1 \mathrm{a}$ & $3.5 \mathrm{ab}$ & $11.8 \mathrm{abc}$ & $5.3 \mathrm{bcd}$ & $17.1 \mathrm{ab}$ \\
\hline G. sepium $(\mathrm{L})$ & $5.8 \mathrm{ab}$ & $5.6 \mathrm{ab}$ & $1.0 \mathrm{a}$ & $14.6 \mathrm{ab}$ & $3.2 \mathrm{ab}$ & $12.3 \mathrm{ab}$ & $5.6 \mathrm{ab}$ & $17.9 \mathrm{a}$ \\
\hline G. sepium (B) & $5.4 \mathrm{ab}$ & $5.6 \mathrm{ab}$ & $1.0 \mathrm{a}$ & $15.0 \mathrm{ab}$ & $2.9 \mathrm{~b}$ & $11.8 \mathrm{abc}$ & $5.6 \mathrm{ab}$ & $17.5 \mathrm{ab}$ \\
\hline G. sepium $(\mathrm{L}+\mathrm{B})$ & $5.9 \mathrm{a}$ & $5.5 \mathrm{ab}$ & $1.0 \mathrm{a}$ & $14.7 \mathrm{ab}$ & $3.1 \mathrm{~b}$ & $12.5 \mathrm{a}$ & $5.7 \mathrm{a}$ & $18.3 \mathrm{a}$ \\
\hline F values & $3.5^{* *}$ & $4.5^{*}$ & $0.0^{\mathrm{ns}}$ & $3.0^{*}$ & $3.0^{*}$ & $12.2 * *$ & $14.8^{* *}$ & $16.9 * *$ \\
\hline CV $(\%)$ & 8.0 & 3.9 & 5.1 & 3.7 & 9.2 & 5.2 & 2.6 & 3.7 \\
\hline
\end{tabular}

Means followed by the same letter in the column did not differ by the Tukey test at $\mathrm{p}<0.05$; **Significant at $\mathrm{p}<0.01$; *Significant at $\mathrm{p}<0.05 ;{ }^{\mathrm{ns}}$ Not significant at $\mathrm{p}<0.05$; $(\mathrm{L})=$ Leaves, $(\mathrm{B})=$ Branches and $(\mathrm{L}+\mathrm{B})=$ Leaves + Branches; $\mathrm{CV}=$ Coefficient of variation. 
There was no statistical difference between treatments regarding the $\mathrm{Al}^{+}$content (Table 6), which decreased compared to the value observed in the characterization of the soil used for cultivation $\left(2.0 \mathrm{mmol} \mathrm{dm}{ }^{-3}\right)$. According to Iwata et al. (2012), a reduction in $\mathrm{Al}^{+3}$ contents is associated with the effect of soil organic matter, which acts by complexing the free aluminum in solution.

For potential acidity $(\mathrm{H}+\mathrm{Al})$, there was a significant difference only when the soil received leaves + branches of $M$. hostilis (highest value) and branches of $M$. caesalpiniifolia (lowest value). Aluminum saturation (m) significantly increased with the application of $M$. hostilis leaves, thus this treatment contributed to the highest mean and statistically differed only from the application of branches of G. sepium and leaves + branches of G. sepium.

The $\mathrm{NO}_{3}^{-}-\mathrm{N}$ content in the soil was affected by the addition of leguminous species residues, except for the leaves of M. caesalpiniifolia, which had a mean statistically equal to that of the control (Table 6). The highest $\mathrm{NO}_{3}{ }^{-}-\mathrm{N}$ content was observed with the application of leaves + branches of G. sepium; however, it did not differ statistically from leaves of G. sepium, branches of G. sepium and leaves + branches of $M$. hostilis. The increase in $\mathrm{NO}_{3}{ }^{-} \mathrm{N}$ content caused by the addition of leaves + branches of $G$. sepium in relation to the control was equal to $26.4 \%$.

As for the $\mathrm{NH}_{4}{ }^{+} \mathrm{N}$ in the soil, the leaves + branches of $G$. sepium resulted in a higher mean, which was higher than the treatments with leaves of $M$. hostilis, branches of $M$. hostilis, leaves + branches of $M$. hostilis, leaves of M. caesalpiniifolia, branches of M. caesalpiniifolia and the control, which showed the lowest content (Table 6). The increment in $\mathrm{NH}_{4}{ }^{+}-\mathrm{N}$ caused by the addition of leaves of $G$. sepium compared to the control was $15.9 \%$.

The $\mathrm{NO}_{3}^{-}-\mathrm{N}+\mathrm{NH}_{4}^{+}-\mathrm{N}$ content (Table 6) follows the same tendency that occurred for $\mathrm{NO}_{3}{ }^{-} \mathrm{N}$ and $\mathrm{NH}_{4}{ }^{+}-\mathrm{N}$. In general, the residues that contain leaves resulted in higher soil $\mathrm{N}$ contents, especially G. sepium. This can be explained by the fact that this species showed the lowest $\mathrm{C}: \mathrm{N}$ ratio in both leaves and branches (Table 1), which favors faster residue decomposition. Thus, $\mathrm{N}$ is more rapidly released into the soil, especially in the first $10 \mathrm{~cm}$, where the mineralization of the biomass of the leguminous plants is most intense. These results corroborate those of Beedy et al. (2010), who worked with G. sepium intercropped with maize in South Africa and observed a positive effect of its biomass on the contents of $\mathrm{NO}_{3}{ }^{-}-\mathrm{N}$ and $\mathrm{NH}_{4}{ }^{+}-\mathrm{N}$ in the soil.

There was predominance of $\mathrm{N}$ in the nitric form $\left(\mathrm{NO}_{3}{ }^{-}-\mathrm{N}\right)$ and these data are consistent with what is expected for aerated soils. Usually, the superficial soil layer has favorable conditions for the nitrification process, in which the ammoniacal $\mathrm{N}$ is transformed to nitric N (MAIA et al., 2008). Thus, the residues of leguminous plants caused the release of $\mathrm{N}$, i.e., there was no limitation to the nitrification process.

Regarding $\mathrm{K}$ content (Table 7) except for leaves of $M$. hostilis and leaves + branches of $M$. hostilis, the studied residues have great potential regarding the release of $\mathrm{K}$ in the soil and $G$. sepium is the best species for this purpose. This is explained by the fact that G. sepium has higher $\mathrm{K}$ contents comparied to the others, in both leaves and branches (Table 1). Santos et al. (2010) also report that the K contents in the plots fertilized with G. sepium were higher than that found in the control during the first year of maize cultivation.

Under the conditions of the present study, leaves + branches of G. sepium caused higher $\mathrm{Ca}$ content, compared with the control. In relation to the other leguminous plants however, it differed statistically only from the leaves of $M$. caesalpiniifolia. The superiority observed in the release of this nutrient through the application of leaves + branches of $G$. sepium is explained by the fact that this species presented a higher $\mathrm{Ca}$ content and a lower $\mathrm{C}: \mathrm{N}$ ratio (Table 1), favoring the decomposition and mineralization of this cation. Low efficiency of leguminous trees to recycle $\mathrm{Ca}$ of the soil, compared with the control treatment, was also reported by Nascimento et al. (2003).

The soil $\mathrm{Mg}$ content was affected by the addition of the residues of leguminous plants and the highest means were obtained by adding leaves of G. sepium and leaves + branches of G. sepium, which were the only treatments that led to means higher than the control (Table 4). There was a $44 \%$ increase in soil $\mathrm{Mg}$, comparing the means of the treatment with leaves of G. sepium (highest mean) and the control. The effect of green fertilizers on the increase of $\mathrm{Mg}$ in the soil was also observed by Nascimento et al. (2003) and Faria et al. (2007).

With regard to $\mathrm{Na}$, higher contents were observed in the treatments with branches of $M$. hostilis, leaves + branches of G. sepium and the control. These three did not differ statistically and were superior only to the application of leaves of $M$. caesalpiniifolia. According to the characterization analysis of the soil used, Na content increased in all treatments, since the initial content was $4.2 \mathrm{mmol}_{\mathrm{c}} \mathrm{dm}^{-3}$ and such an increase is related to the irrigation water. Regarding the difference between treatments, the highest $\mathrm{Na}$ contents were observed in the soil that received residues containing branches and in the control. Hence, soils with little or no cover favor higher evaporation of the irrigation water, thus increasing the capillary rise of salts (particularly $\mathrm{Na}$ ) to the surface of the pots. 
F. R. A. OLIVEIRA et al.

Table 7. Mean values of the contents of phosphorus $(\mathrm{P})$, potassium $(\mathrm{K})$, calcium $(\mathrm{Ca})$, magnesium $(\mathrm{Mg})$, sodium $(\mathrm{Na})$, sum of bases (SB), cation exchange capacity (T), effective cation exchange capacity (t) and base saturation (V) in the first $10 \mathrm{~cm}$ of the soil after maize cultivation with addition of residues of leguminous trees.

\begin{tabular}{|c|c|c|c|c|c|c|c|c|c|}
\hline \multirow{2}{*}{ Treatments } & $\mathrm{P}$ & K & $\mathrm{Ca}$ & $\mathrm{Mg}$ & $\mathrm{Na}$ & SB & $\mathrm{T}$ & $\mathrm{t}$ & $\mathrm{V}$ \\
\hline & $\mathrm{mg} \mathrm{dm}{ }^{-3}$ & \multicolumn{7}{|c|}{ 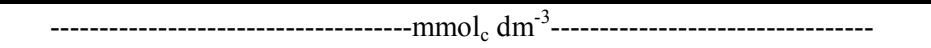 } & $\%$ \\
\hline Without residue & $4.1 \mathrm{a}$ & $1.5 \mathrm{~d}$ & $13.2 \mathrm{~b}$ & $4.8 \mathrm{c}$ & $7.9 \mathrm{a}$ & $27.0 \mathrm{de}$ & $40.6 \mathrm{~d}$ & 28.0 de & $65.9 \mathrm{abc}$ \\
\hline M. caesalpiniifolia $(\mathrm{L})$ & $4.0 \mathrm{a}$ & $2.6 \mathrm{c}$ & $13.1 \mathrm{~b}$ & $5.0 \mathrm{bc}$ & $6.1 \mathrm{~b}$ & $26.3 \mathrm{e}$ & $40.2 \mathrm{~d}$ & $27.3 \mathrm{e}$ & $64.7 \mathrm{c}$ \\
\hline M. caesalpiniifolia $(\mathrm{B})$ & $4.2 \mathrm{a}$ & $2.3 \mathrm{c}$ & $13.9 \mathrm{ab}$ & $5.9 \mathrm{abc}$ & $7.6 \mathrm{ab}$ & 28.7 bcde & $44.2 \mathrm{abcd}$ & $29.7 \mathrm{bcd}$ & $68.9 \mathrm{ab}$ \\
\hline M. caesalpiniifolia $(\mathrm{L}+\mathrm{B})$ & $4.1 \mathrm{a}$ & $2.5 \mathrm{c}$ & $13.7 \mathrm{ab}$ & $4.8 \mathrm{bc}$ & $7.6 \mathrm{ab}$ & $28.3 \mathrm{cde}$ & $43.8 \mathrm{bcd}$ & 29.3 cde & $66.2 \mathrm{abc}$ \\
\hline M. hostilis (L) & $4.1 \mathrm{a}$ & $2.1 \mathrm{~cd}$ & $13.4 \mathrm{ab}$ & $5.3 \mathrm{bc}$ & $7.4 \mathrm{ab}$ & $27.6 \mathrm{de}$ & $43.1 \mathrm{~cd}$ & $28.7 \mathrm{cde}$ & $65.3 \mathrm{abc}$ \\
\hline M. hostilis (B) & $4.2 \mathrm{a}$ & $2.4 \mathrm{c}$ & $13.8 \mathrm{ab}$ & $5.9 \mathrm{abc}$ & $7.8 \mathrm{a}$ & $29.0 \mathrm{bcd}$ & $45.2 \mathrm{abc}$ & $30.0 \mathrm{bcd}$ & $67.5 \mathrm{abc}$ \\
\hline M. hostilis $(\mathrm{L}+\mathrm{B})$ & $4.1 \mathrm{a}$ & $2.0 \mathrm{~cd}$ & $13.5 \mathrm{ab}$ & $4.9 \mathrm{bc}$ & $7.4 \mathrm{ab}$ & $27.4 \mathrm{de}$ & $43.0 \mathrm{~cd}$ & $28.4 \mathrm{de}$ & $64.9 \mathrm{bc}$ \\
\hline G. sepium (L) & $4.1 \mathrm{a}$ & $4.1 \mathrm{~b}$ & $13.7 \mathrm{ab}$ & $6.9 \mathrm{a}$ & $6.9 \mathrm{ab}$ & $30.1 \mathrm{abc}$ & $46.5 \mathrm{abc}$ & $31.1 \mathrm{abc}$ & $68.5 \mathrm{abc}$ \\
\hline G. sepium (B) & $4.2 \mathrm{a}$ & $4.9 \mathrm{a}$ & $13.6 \mathrm{ab}$ & $5.3 \mathrm{bc}$ & $7.7 \mathrm{ab}$ & $32.4 \mathrm{a}$ & $48.2 \mathrm{a}$ & $33.4 \mathrm{a}$ & $68.8 \mathrm{ab}$ \\
\hline G. sepium $(\mathrm{L}+\mathrm{B})$ & $4.1 \mathrm{a}$ & $4.1 \mathrm{~b}$ & $14.0 \mathrm{a}$ & $6.2 \mathrm{ab}$ & $7.8 \mathrm{a}$ & $31.0 \mathrm{ab}$ & $47.8 \mathrm{ab}$ & $32.0 \mathrm{ab}$ & $69.2 \mathrm{a}$ \\
\hline F values & $0.0^{\mathrm{ns}}$ & $100,9^{* *}$ & $3.2 * *$ & $6.2^{* *}$ & $2.6^{*}$ & $13.4 * *$ & $10.2 * *$ & $13.6^{* *}$ & $4.6^{* *}$ \\
\hline CV $(\%)$ & 9.5 & 7,7 & 2.4 & 10.1 & 8.9 & 3.6 & 3.8 & 3.8 & 2.4 \\
\hline
\end{tabular}

Means followed by the same letter in the column do not differ by Tukey test at $\mathrm{p}<0.05$; **Significant at $\mathrm{p}<0.01$; $*$ Significant at $\mathrm{p}<0.05$; nsNot significant at $\mathrm{p}<0.05 ;(\mathrm{L})=$ Leaves, $(\mathrm{B})=$ Branches and $(\mathrm{L}+\mathrm{B})=$ Leaves + branches; CV $=$ Coefficient of variation.

For the parameter sum of bases (SB), the addition of branches of $G$. sepium led to the highest mean, which was statistically equal to the treatments with leaves + branches of $G$. sepium and leaves of G. sepium and higher than the others (Table 7). The highest SB associated with the residues of $G$. sepium is consistent with the contents of $\mathrm{K}, \mathrm{Ca}$ and $\mathrm{Mg}$ caused by the residues of this leguminous plant. The use of leguminous species capable of producing large amounts of residues favors reduction in the leaching of cations and increase in CEC, which is promoted by proportional increments in $\mathrm{Ca}, \mathrm{Mg}$ and $\mathrm{K}$ contents and consequently in the sum of bases of the soil (TESTA; TEIXEIRA; MIELNICZUK, 1992).

Regarding cation exchange capacity (T), only the residues of $G$. sepium and branches of $M$. hostilis resulted in means higher than those of the control (Table 7). As mentioned for the sum of bases, the results of $\mathrm{T}$ are consistent with the observed contents of $\mathrm{K}, \mathrm{Ca}, \mathrm{Mg}$ and $\mathrm{H}+\mathrm{Al}$. As to the effective cation exchange capacity (t), the residues of $G$. sepium were the only ones to cause means higher than those of the control.

The results for $\mathrm{T}$ and $\mathrm{t}$ follow the same tendency, evidencing that the residues of G. sepium added to the soil led to the highest values of cation exchange capacity (CEC) at 65 days after application. According to Iwata et al. (2012), the CEC of soils with higher SOM contents, as occurred in the soil that received leaves + branches of G. sepium compared with the control, is also influenced by the high reactive power of the SOM, which is directly related to its various organic radicals.

For base saturation (V), there was no significant difference between the soil that received leguminous plants residues and the control. In this regard, Nascimento et al. (2003) found that the leguminous species pigeon pea (Cajanus cajan (L) Millsp.), brown hemp (Crotalaria juncea, L.) and velvet bean (Stizolobium aterrimum Piper \& Tracy), despite promoting higher absolute values, did not differ significantly from an area without cultivation with respect to the effect on V. It is worth highlighting that high $\mathrm{V}$ is not always associated with fertile soil, as in the case of soils that have high $\mathrm{Na}$ contents due to irrigation with lower-quality water. This ion is not beneficial to the plants, but occupies the exchange site and is taken into account in the sum of bases, thus contributing to higher values of $\mathrm{V}$.

\section{CONCLUSIONS}

Residues of $M$. caesalpiniifolia, M. hostilis and $G$. sepium positively influenced the growth of maize plants and favored the accumulation of macronutrients in the shoots, especially $\mathrm{N}, \mathrm{P}$ and $\mathrm{K}$ at 65 days after applying the residues.

Green fertilization with residues of $M$. caesalpiniifolia, M. hostilis and G. sepium improved soil chemical attributes at 65 days after application, especially $\mathrm{NH}_{4}{ }^{+}-\mathrm{N}, \mathrm{NO}_{3}{ }^{-}-\mathrm{N}, \mathrm{NO}_{3}{ }^{-}-\mathrm{N}+\mathrm{NH}_{4}{ }^{+}-\mathrm{N}$ and $\mathrm{K}$.

The improvements in soil chemical attributes caused by residues of $M$. caesalpiniifolia, $M$. hostilis and $G$. sepium demonstrate that these species are good options for recovering degraded areas in the semi-arid region of the Ceará state.

\section{REFERENCES}


ANDRADE NETO, R. C. et al. Crescimento e produtividade do sorgo forrageiro BR 601 sob adubação verde. Revista Brasileira de Engenharia Agrícola e Ambiental, Campina Grande, v. 14, n. 2, p. $124-130,2010$.

BAKKE, I. A. et al. Forage yield and quality of a dense thorny and thornless "jurema-preta" stand. Pesquisa Agropecuária Brasileira, Brasília, v. 42, n. 3, p. 341-347, 2007.

BEEDY, T. L. et al. Impact of Gliricidia sepium intercropping on soil organic matter fractions in a maize-based cropping system. Agriculture, Ecosystems and Environment, Amsterdam, v. 138, n. 3-4, p. 139-146, 2010.

DINIZ, E. R. et al. Efeito de doses de adubo verde no crescimento e produção de brócolis orgânico. Horticultura Brasileira, Brasília, v. 28, n. 2, p. 2819-2826, 2010.

DONAGEMA, G. K. et al. Manual de métodos de análises de solos. 2. ed. Rio de Janeiro: Embrapa Solos, 2011. 230 p. (Documentos, 132).

\section{EMPRESA BRASILEIRA DE PESQUISA AGROPECUÁRIA - EMBRAPA. Mapa Exploratório-Reconhecimento de solos do município de Sobral-CE. Recife, 2006. Embrapa Solos UEP Recife. Escala 1:600.00. Disponível em: $<$ http://www.uep.cnps.embrapa.br/solos/index.php? link $=$ ce $>$. Acesso em: 10 set. 2017.}

ERNANI, P. R.; ALMEIDA, J. A.; SANTOS, F. C. Potássio. In: NOVAIS, R. F. et al. (Eds.). Fertilidade do solo. Viçosa: Sociedade Brasileira de Ciência do Solo, 2007. cap. 9, p. 551-594.

FARIA, C. M. B. et al. Atributos químicos de um argissolo e rendimento de melão mediante o uso de adubos verdes, calagem e adubação. Revista Brasileira de Ciência do Solo, Viçosa, v. 31, n. 2, p. 299-307, 2007.

FERNANDES, V. L. B. Recomendações de adubação e calagem para o estado do Ceará. Fortaleza, CE: Imprensa Universitária, 1993. 247 p.

FERREIRA, D. F. Sisvar: A computer statistical analysis system. Ciência e Agrotecnologia, Lavras, v. 35, n. 6, p. 1039-1042, 2011.

FERREIRA, R. L. C. et al. Deposição e acúmulo de matéria seca e nutrientes em serapilheira em um bosque de sabiá (Mimosa caesalpiniifolia Benth). Revista Árvore, Viçosa, v. 31, n. 1, p. 7-12, 2007.

FONTANÉTTI, A. et al. Adubação verde na produção orgânica de alface americana e repolho.
Horticultura Brasileira, Brasília, v. 24, n. 2, p. 146150,2006

IWATA, B. F. et al. Sistemas agroflorestais e seus efeitos sobre os atributos químicos em Argissolo Vermelho-Amarelo do Cerrado piauiense. Revista Brasileira de Engenharia Agrícola e Ambiental, Campina Grande, v. 16, n. 7, p. 730-738, 2012.

MAIA, S. M. F. et al. Frações de nitrogênio em Luvissolo sob sistemas agroflorestais e convencional no semiárido cearense. Revista Brasileira de Ciência do Solo, Viçosa, v. 32, n. 1, p. 381-392, 2008.

MARIN, A. M. P. et al. Efeito da Gliricidia sepium sobre nutrientes do solo, microclima e produtividade do milho em sistema agroflorestal no Agreste Paraibano. Revista Brasileira de Ciência do Solo, Viçosa, v. 30, n. 3, p. 555-564, 2006.

MUNDUS, S. et al. Maize growth and soil nitrogen availability after fertilization with cattle manure and/ or gliricidia in semiarid NE Brazil. Nutrient Cycling in Agroecosystems, Amsterdam, v. 82, n. 1, p. $61-73,2008$.

NASCIMENTO, T. J. et al. Efeito de leguminosas nas características químicas e matéria orgânica de um solo degradado. Revista Brasileira de Engenharia Agrícola e Ambiental, Campina Grande, v. 7, n. 3, p. 457-462, 2003.

PAULINO, G. M. et al. Desempenho da gliricídia no cultivo em aleias em pomar orgânico de mangueira e gravioleira. Revista Árvore, Viçosa, v. 35, n. 4, p. 781-789, 2011.

PEREIRA, N. S.; SOARES, I.; MIRANDA, F. R. Decomposition and nutrient release of leguminous green manure species in the Jaguaribe-Apodi region, Ceará, Brazil. Ciência Rural, Santa Maria, v. 46, n. 6, p. 970-975, 2016.

PRIMO, D. C. et al. Contribuição da adubação orgânica na absorção de nutrientes e na produtividade de milho no semiárido paraibano. Revista Brasileira de Ciências Agrárias, Recife, v. 7, n. 1, p. 81-88, 2012.

SAMPAIO, L. R. et al. Cultivo de abóbora, suplementada com biofertilizante, em aleias de leguminosas arbóreas. Horticultura brasileira, Brasília, v. 33, n. 1, p. 40-44, 2015.

SANTOS, A. F. et al. Efeito residual da adubação orgânica sobre a produtividade de milho em sistema agroflorestal. Revista Brasileira de Engenharia Agrícola e Ambiental, Campina Grande, v. 14, n. 12 , p. $1267-1272,2010$ 
SILVA, F. C. Manual de análises químicas de solos, plantas e fertilizantes. 2. ed. Brasília, DF: Embrapa Informação Tecnológica, 2009. 627 p.

SILVA, I. R.; MENDONÇA, E. S. Matéria orgânica do solo. In: NOVAIS, R. F. et al. (Eds.). Fertilidade do solo. Viçosa: Sociedade Brasileira de Ciência do Solo, 2007, cap. 6, p. 275-374.

SOUZA, H. A. et al. Use of organic compost containing waste from small ruminants in corn production. Revista Brasileira de Ciência do Solo, Viçosa, v. 40, n. 1, p. 1-16, 2016.

SOUZA, H. A. et al. Diagnóstico da fertilidade do solo em áreas de sequeiro de agricultores familiares em municípios do Sertão dos Inhamuns, Ceará. 1. ed. Sobral: Embrapa Caprinos e Ovinos, 2015.9 p. (Comunicado Técnico, 145).

TESTA, V. M.; TEIXEIRA, L. A. J.; MIELNICZUK, J. Características químicas de um Podzolico Vermelho-Escuro afetadas por sistemas de culturas. Revista Brasileira de Ciência do Solo, Viçosa, v. 1, n. 16, p. 107-114, 1992. 